\title{
Theories and Models Regarding Formal / Informal Duality of the Labor Market
}

Cristian MARINESCU ${ }^{1}$

\section{Abstract}

This work proposes an incursion, from a theoretical point of view, in the specialized literature that has, over time, approached the labor market through the formal / informal duality.

From the review of the specialized literature, I found that the studies on the duality of the labor market were based on aspects related to: the bureaucracy or the regulations existing on the two types of labor markets (formal/informal), productivity, rigidity, of the salaries practiced on the two types of markets, as well as the option of employees for formal or informal, depending on the cost benefit analysis.

In this paper we intend to detail the models and theories with specialized literature is currently operating to characterize the labor market, through the formal/informal duality, respectively models based on the aspect of: bureaucracy /market regulations (Hart, Soto, $I L O)$, productivity (Lewis), rigidity (Joshi, Hield), wages (Kuznets, Field) or employee choice (Maloney, Perry).

Keywords: duality of the labor market, informality

JEL classification J20, O17

DOI: $10.24818 / \mathrm{RMCI} .2019 .4 .428$

\section{Introduction}

In the "formal sector" of the economy, there are three categories of agents, namely: economic agents, which can be individual or legal persons and which act as traders, consumers but also employers of labor force; individuals, who participate in the economic life as consumers or as labor force bidders; and the state, which acts as a service provider to the population, as a consumer but also as a labor force employer.

The three categories of agents can be found on various economic markets, such as: the services and/or goods market - when they act as producers of services and/or goods providers, on the hand, and on the other hand as of consumers; the monetary market - when within the various activities between these agents there are money transfers; financial market or capital market - when the agents want to invest in various financial products or when the holders of such financial instruments want to convert them into liquidity; the foreign exchange market - when the object of the

\footnotetext{
${ }^{1}$ Cristian Marinescu, Romanian Court of Accounts, Email: cristian.marinescu@ macroeconomie.ro
} 
transaction is represented by the foreign currency and, last labor market - when labor force purchase and sale documents take place.

The activities that are taking place in all categories of economic markets listed above, can have both a "formal" form, when these activities comply with the regulations specific to each market category or can have an "informal" form, when they are taking place behind the regulations established by state, being invisible to the authorities, and cannot be monitored, quantified and taxed.

There are several models and theories that refer to the formal/informal duality of labor market, to which a number of authors have contributed, including: Torado and Harris, Gary F., Maloney W., Kuznets S, Hart K., Kanbur R., or institutions, such as the International Labor Office, the World Bank etc.

These models analyze the way and the degree to which different components of the formal/informal dual system are influenced by distinct parameters, like: productivity, rigidity, bureaucracy (the laws system), the salary or the option of the workers.

\section{Productivity}

The dualistic modeling of the economy, based on the formal/informal antithesis, started from the theory of economic development with unlimited supply of labor belonging to Arthur Lewis (1954), who postulated the existence of two very differentiated sectors, namely the rural sector (of subsistence agriculture) and the urban sector (of capital accumulation), where productivity is much larger than agriculture. The urban sector allows savings and therefore investments, and this will lead to increase labor demand. This will be supplemented by attracting the labor force from the rural sector, which is overcrowded, and labor productivity is low. Thus, there will be a migration of the labor force from the rural sector, occupied in subsistence agriculture, to the urban sector, ensuring a sustainable development.

\section{Bureaucracy / Legality}

Theories regarding to formal/informal duality of labour market that emphasize the legislative framework belong to authors such as Hart, Field or de Soto.

Referring to the dual character of the economy, Hart considers that certain activities and societies are formal meaning they are carried out in a legal framework and are subject to special regulations, while others "take place behind the effective regulations of the state" (Hart, 2001).

From a bureaucratic point of view, the reporting of "informal sector" of the economy to the regulations of "formal sector" can be done in one of the following four situations: as a division, as a content, as a negation or as a residue (Hart, 2006).

The organization of formal sector implies choice that people make in terms of the quality in which they can appear every day of the economic life, respectively as producers or consumers, performing paid or unpaid work, having the opportunity to opt for a job, or having the freedom to do what they want with their free time. 
Money is the means by which the two variants (work or spend their leisure otherwise) are balanced, and people opt for one of the two variants in a process called "division".

In order for any rule to be translated into a human action, personal appreciation or judgment must necessarily appear. Thus, informality appears in bureaucratic forms as an unspecified "content". Informal can be a variable of the formal so it can be regarded as "content".

Failure to comply with regulations takes place both within and outside the bureaucracy. Thus, negation appears, the third way in which informal activities relate to formality. The informal can be a denial, a non-recognition of the formal institutions and appears in the form of tax evasion or fraud.

Often, informality comes in the form of illegality. However, the informal sector appears to be a legitimate segment of the economy because it is hard to draw a line between "women selling oranges on the street and gangsters taking their protection fee." Often, a legislative vacuum is immediately speculated on by individuals in society, through a criminal activity. Some informal activities exist in parallel with the formal ones, as a "residue" of them, and the demarcation between the two is done by the bureaucracy. This is the fourth way the informal sector is linked to formal sector (Hart, 2006).

The dualism of the labor market, which implies the existence of two sectors operating in the economy, can be synthesized most suggestively by the expressions: "segmentation of the labor market" or "fragmentation of the labor market" (Fields, 2008, p. 4).

The difference between the two sectors consists in the fact that the legal status is the one that makes the difference between formal and informal (De Soto, 1972), as well as in the fact that informality is synonymous with tax evasion (avoiding, avoiding debt payments to the state) (ILO, 1972).

\section{Rigidity}

Unlike formal labor market, considered as a lack of flexibility, the informal labour market, regardless of speak about a developed economy or a poor one, is usually a flexible one, because the inputs and outputs from the informal labour are very high. The transition from one economic activity to another as well as having more jobs are very common in the informal economy and are often related to seasonal or/and occasionally job in agriculture. Also, work informality it's just a temporary stage for new workers to the labour market, particularly in developing economies, where young workers, due to the lack of experience needed in most formal works, prefers informal employment for a certain period. Although formal jobs are characterized by great flexibility, they are still unstable and this is primarily due to the easy degree of entry and exit into / from these jobs (Joshi, 1997, p. 39).

Based on the studies, which approached the duality of the informal/formal sectors throughout an economic cycle, the following conclusions can be drawn (Perry, Maloney et al, 2007, p. 1, 2): 
- The formal system is rigid and has high costs;

- The informal system absorbs the workers dismissed from the formal sector;

- Formal firms become partially formal by employing workers without legal forms.

\section{Wage theories}

A characteristic feature of developing economies refers to the fact that workers earn different wages depending on the type of work place, formal or informal in which they work. Lewis says, "the earnings in the subsistence sector have established a bridge to the wages in the capitalist sector, but in practice, the wages in the formal sector must be higher than the earnings in the subsistence sector, and there is usually a gap of $30 . \%$ or more between capitalist wages and subsistence earnings". Lewis explained the difference between formal sector and subsistence income as inconclusive due to the high cost of urban living, but nonetheless, between the two categories of incomes there is a gap due to (Lewis, 1954, pp. 400 - 449):

- the psychological cost implecated in the transfer from the simplistic way of life from the subsistence economy to the more complex way of life in the capitalist sector in the urban sector;

- the increases experience of the workers in the capitalist sector;

- the social prestige of workers in the capitalist sector that must be extra paid.

A well-known model which refers to the formal/informal duality of the labor market from the perspective of wages is the dual wage model developed by Kuznets. He developed the model of dual wages for the two sectors of the economy by exploring how income inequality could change the way in which high incomes in a sector would attract a larger share of the population. All these inequalities established by Kuznets (the share of the income of the poorest $20 \%$ of the population in the share of the income of the richest $20 \%$ of the population) represented the "inverted $U$ " model, which later became known as the Kuznets Curve (Kuznets, 1955).

Another model which approaches the formal/informal duality of the labor market from the wage perspective is that developed by Perry \& Maloney. They believe that a high level of leaving the formal sector can make companies in the formal sector to pay employees higher incomes than the "efficiency wage", to ensure that the best-trained and productive employees will remain in the firm (Perry, Maloney and col., 2007, p. 44; Stiglitz and Sapiro, 1984).

Unlike large companies, from the formal sector of the economy, small firms, from the informal sector, can monitor their employees without additional costs and therefore do not have to pay the employees the efficiency wage in order for them to work as productive as possible (Esfahani and Salhi-Isfahani, 1989; Stiglitz and Sapiro, 1984). 
Also, because of the asymmetric information, young employees, without a work history, will find it harder formal employers willing to hire them, precisely because of their lack of experience, which is why young people could accept an informal and lower paid job until they have enough experience to compete in the formal labor market (Perry, Maloney et al., 2007, p. 44).

Fields creates a set of four alternative models that analyze the wage and behavior of firms and employees in direct connection with the demand and supply of labor force, which may or may not be influenced by government regulations. Fields (2008) developed the "salaries that are freely formed on the market" model. According to this model, there are three forces on the market, namely: the behavior of companies, the behavior of workers and the behavior of wages.

In this model, the companies have the freedom to hire or not workers according to the conditions existing at a given moment in the market, starting from their interest to maximize their profit. In their turn, workers are free to provide labor or not, depending on what they think is best for them. Also, depending on the conditions and the changes that have occurred on the market, real wages are free to increase or decrease (Fields, 2008, p. 9).

Another important model worth mentioning here is that of "institutionally established salaries", also developed by Fields. In this model, according to the realities of some countries, the salaries in the formal sector are set, not for reasons of maximizing the profit of the companies or for the interest of the workers, meaning based on the demand and supply of work, but they are established by what is called "Institutional forces". The institutional forces include the minimum wage, trade unions, wage policies of public sector, multinational corporations and the labor code, as follows:

- Minimum wage: which aims to provide workers an adequate standard of living;

- Trade Unions: they aim to obtain for workers the best wages and working conditions;

- Wage policies of public sector: they often lead to higher salaries for civil servants than for private sector workers;

- Multinational corporations: they often pay salaries above the market level, and the wage level tends to be higher in export-oriented firms than in the ones they produce for the domestic market;

- Labor Code: in some countries, they place stricter conditions for dismissal and require companies to grant certain benefits to their workers.

The result of an outside labor market intervention, which determines to a large extent the wage incomes, is a negative elasticity of the wages of the workers in the formal system. This results in a decrease in the efficiency of the firms, which lead to unemployment and, finally, to the reduction of the formal system and the increase of the informal one (Fields, 2008, p. 10-12).

Another two essential models regarding the salary, developed by Fields too, there are: "The model of salaries established for reasons of wage efficiency" and "The model of salaries established on the basis of work demand". 
In human resources management it is stated that a firm can increase labor productivity by paying higher wages (Leibenstein, 1957; Stiglitz, 1974; Weiss, 1991). But, a company seeks to make as much profit as possible, which may or may not be achieved through higher productivity. These companies will pay higher salaries only if the costs are lower than the incomes obtained. Regarding the first model, there are two explanations for which a higher wage determines an increased labor productivity:

- The first refers to the fact that high salaries allow companies to hire educated workers with a better skills

- The second explanation refers to the fact that high salaries lead to morale improvement of the workers, induces their desire for emulation, reduces their self-avoidance and absenteeism.

Unemployment, which may appear in this approach, is due to the fact that firms do not want to reduce wages, even if some of the unemployed would be willing to work on lower wages than to remain unemployed (Fields, 2008, p. 13-14).

The model of salaries established on the basis of work demand refers to the wages that were above the level of the labor market in a certain period, after which a period of stagnation of the economic activities follows. According to market laws, the unemployed would offer to work on lower wages. However, the supply behavior of workers differs from the standard response expected from them, especially in the case of a demand for inelastic workforce. In this case, the unemployed will refuse to receive a lower salary than had been established before the economic stagnation, so that the wage will remain above the market level (Fields, 2008, pp. 14-15).

\section{The workers' option}

A first model that is based on the workers' option is the model developed by Harris and Todaro in 1970. Referring to the agriculture work sector, the authors assume that anyone who wants to work in agriculture can find a free plot of land, it can cultivate it and then gain the marginal productivity of its own work effort invested in that activity. This type of subsistence farming work that ensures survival can be an alternative to working in the formal sector for a short period of time (Harris, Todaro, 1970).

Another approach of the informal sector of the economy that takes into account the option of the workers was developed, more recently, by a new model, by William Maloney, the representative of the volunteer school. The voluntary school sees the informal sector of the economy as being made up of economic agents who choose to operate informally in order to avoid the fiscal, financial and commercial regulations of the state. Unlike legalists, the volunteer school does not invoke the complicated bureaucracy of formality, but only the financial benefits that informality brings by avasion (elusion the payment of taxes), this option being done after a cost-benefit analysis of the two sectors of the economy. 
In assessing the opportunity cost of choosing the informal sector of the economy, the economic agents take into account the contraventional or penal sanctions of informality.

Maloney offers a number of reasons why workers might prefer the informal sector: some might earn more (or at least hope to earn more) if they were self employment in informal sector unless they were working in the formal sector; others, rather, would prefer to invest in their own informal business, the amounts of money they would utilize for paying social insurance in formal sector; workers do not value the social health insurance that the formal sector offers and do not trust the government's promises regarding future pension benefits. For these reasons, there could be a considerable number of people who would prefer self-employment in the informal sector than being employed in the formal sector (Maloney, 2003).

\section{Holistic approach}

A holistic approach to informality belongs to Ravi Kanbur (2009). In 2009, he postulated a conceptual framework to distinguish between four types of economic responses to legal regulations, namely:

- Those that are in the field of legal regulations and comply with them;

- Those who remain in the field of legal regulations but do not comply;

- Those who adjust their activity to avoid the legal regulations;

- Those who are outside of the law and do not need to adjust their activity to avoid the legal regulations.

According to the Kanbur s model, the only "formal" category is "1", the rest of the categories being "informal", and of these "2" category is most clearly "illegal". Regarding the categories "3" and "4", Kanbur ascertain: "the law does not apply in this case - as the legislation stipulates a minimum size that the formal firm has, and the companies belonging to categories 3 and 4 are below. the minimum level". However, there is a clear difference between them, namely: category " 3 " is adjusted so that it becomes below the minimum level established by law, while category "4" is below the minimum established by law, so the law does not affect it in any situation (Kanbur, 2009).

\section{Conclusions}

In conclusion, we can say that, although informality is associated with: poverty, underdevelopment, lack of productivity and lack of social protection, it has, within certain limits, positive effects in the economy and we refer here in particular to the fact that informal jobs are more flexible than the formals, as well as the fact that informality can be an alternative for that category of workers who, for different reasons, cannot have access to formal jobs (lack of experience, insufficient jobs, inadequate wages etc.).

Therefore, some of the informality should be tolerated by the state. A completely formal system would not be efficient neither for workers and businesses,

$434 \quad$ Volume 20, Issue 4, October 2019 Review of International Comparative Management 
nor for the state. And this is because employment in the informal sector of the economy is a better solution than unemployment.

\section{Acknowledgement}

This paper is a result of research from the Human Capital Operational Program 2014-2020, project number POCU / 380/6/13/125245 no. 36482 / 23.05.2019 "Excellence in interdisciplinary $\mathrm{PhD}$ and post-PhD research, career alternatives through entrepreneurial initiative (EXCIA)", coordinator The Bucharest University of Economic Studies"

\section{References}

1. Fields Gary S, 2008," Segmented Labour Market models in developing countries", Cornell University ILR School, paper 162;

2. Harris John, Todaro Michael, 1970, "Migration, Unemployment and Development: A Two-Sector Analysis", American Economic Review 60 (1), pp. 126-142;

3. Hart Keith, 2001, " Money in an Unequal World", Texere Books;

4. Hart Keith, 2006, " Bureaucratic form and the informal economy", In linking the Formal and Informal Economy: Concepts and Policies, edited by Basudeb Guha Khasnobis, Ravi Kanbur and Elinor Ostrom, Oxford University Press;

5. ILO, 1972," Employment, Incomes and Equality. A strategy for increasing productive employment in Kenya", International Labour Office (ILO), Geneva;

6. Joshi Gopal, 1997,"Urban informal sector in Metro Manila: A problem or solution?", ILO (Manila);

7. Kanbur Ravi, 2009, " Conceptualizing Informality: Regulation and Enforcement", Indian Journal of Labour Economics, February;

8. Kuznets Simon, 1955, "Economic Growth and Income Inequality", American Economic Review, Vol. 45, No. 1, pp. 1-28;

9. Lewis W. Arthur, 1954, "Economic Development with Unlimited Supplies of Labor", Manchester School, pp. 400-449;

10. Maloney William F., 2003, "Informal Self-Employment: Poverty Trap or Decent Alternative," in Gary S. Fields and Guy Pfeffermann, eds., Pathways Out of Poverty, Boston;

11. Maloney William, 2003, "Informality revisited", Policy Research Working Paper Series 2965, The World Bank, Volume, (Year), (Month): 32, (2004), 7, pp. 1159-1178;

12. Maloney William F., 2004, "Informality Revisited”, World Development no. 32 (7): pp. 1159-78; 
13. Perry Guilermo, Maloney William and col., 2007, „Informality: Exit and Exclusion", The World Bank, Washington DC;

14. Salehi Esfahani and Salehi-Isfahani Djavad, 1989, "Effort Observability and Worker Productivity: Towards an Explanation of Economic Dualism," Economic Journal, vol. 99, pp. 818-836;

15. Shapiro C., Stiglitz J.E, 1984, "Equilibrium Unemployment as a Worker Discipline Device", American Economic Review, 74 (3), pp. 433-444;

16. de Soto H., 1989, "The Other Path. The Invisibles Revolution in the Third, World", New York: Basic Books;

17. Stiglitz Joseph E, 1974, "Alternative Theories of Wage Determination and Unemployment in LDC'S: The Labor Turnover Model", The Quarterly Journal of Economics, MIT Press, vol. 88 (2), pp. 194-227, May;

18. Weiss A., 1991, "Efficiency Wages", Princeton University Press, Princeton, NJ; 